\title{
KEWENANGAN MAHKAMAH KONSTITUSI DALAM PERLINDUNGAN HAK KONSTITUSIONAL WARGA NEGARA MELALUI KONSTITUSIONAL COMPLAINT
}

\author{
Benito Asdhie Kodiyat MS, Eza Ista Maulida Sinaga \\ Fakultas Hukum Universitas Muhammadiyah Sumatera Utara \\ Jl. Kapten Mukhtar Basri No. 3, Medan - Sumatera Utara \\ Email: benitoasdhie@umsu.ac.id, ezaista.maulida@gmail.com
}

\begin{abstract}
Abstrak
Mahkamah Konstitusi membawa Indonesia menuju demokrasi yang lebih baik. Hal ini disebabkan oleh adanya lembaga terpisah yang secara khusus menjaga martabat UndangUndang Dasar Negara Republik Indonesia Tahun 1945 sebagai norma tertinggi di Indonesia, sehingga segala tindakan yang berkaitan dengan konstitusi dapat ditanggapi secara khusus ke pengadilan konstitusi. Selain itu, posisi Mahkamah Konstitusi dalam struktur kelembagaan negara sebagai lembaga yang setara dengan majelis konsultatif rakyat, majelis perwakilan, dewan perwakilan daerah, presiden, mahkamah agung dan komisi yudisial telah menegaskan bahwa Mahkamah Konstitusi adalah lembaga yang memiliki kewenangan tinggi di koridor kewenangannya. Penelitian adalah alat dasar dalam pengembangan ilmu pengetahuan dan teknologi. Ini karena penelitian bertujuan untuk mengungkapkan kebenaran secara sistematis, metodologis, dan konsisten. Melalui proses penelitian analisis dan konstruksi data yang telah dikumpulkan dan diolah dilakukan. Permasalahan dalam penelitian ini adalah bagaimana konsep pengaduan konstitusional sebagai bentuk perlindungan hak konstitusional warga negara, bagaimana alternatif penerapan kewenangan pengaduan konstitusional di Indonesia. Hasil dari penelitian ini adalah bahwa keluhan konstitusional adalah salah satu mekanisme pertahanan bagi warga negara untuk mempertahankan hak konstitusional mereka melalui pengadilan terhadap pelaksanaan kekuasaan negara.
\end{abstract}

\section{Kata Kunci : Kewenangan, Mahkamah, Konstitusi}

\section{Abstract}

The constitutional court brought Indonesia towards a better democracy. This is due to the existence of a separate institution that specifically safeguards the dignity of the 1945 Constitution of the Republic of Indonesia as the highest norm in Indonesia, so that any actions related to the constitution can be responded specifically to the constitutional court. In addition, the position of the constitutional court in the state institutional structure as an institution that is equal to the people's consultative assembly, the house of representatives, the regional representative council, the president, the supreme court and the judicial commission has affirmed that the constitutional court is an institution that has high authority in the corridors of its authority. The research is a basic tool in the development of science and technology. This is because research aims to express the truth systematically, methodologically, and consistently. Through the research process analysis and construction of data that has been collected and processed is conducted. the problem in this research is how is the concept of constitutional complaints as a form of protection of citizens' constitutional rights, how is the alternative application of constitutional complaints authority in Indonesia. The result of this research is that constitutional complaints are one of the defense mechanisms for citizens to defend their constitutional rights through the courts against the exercise of state power. 
DEIEGA LATA

Jurnal Ilmu Hukum

FAKULTAS HUKUM UMSU
Kewenangan Mahkamah Konstitusi...(Benito Asdhie, Eza Ista)

Volume 4 Nomor 2, Juli-Desember 2019, 160-174

DOI: https://doi.org/10.30596/dll.v4i2.3174

\section{Keywords: Authority, Court, Constitution}

\section{PENDAHULUAN}

Kelahiran Mahkamah Konstitusi membawa Indonesia ke arah demokrasi yang lebih baik. Hal ini karena adanya suatu lembaga tersendiri yang secara khusus menjaga martabat UndangUndang Dasar Republik Indonesia 1945 sebagai norma tertinggi di Indonesia, sehingga setiap tindakan yang berkaitan dengan konstitusi dapat ditanggapi secara khusus pula di Mahkamah Konstitusi. Selain itu, posisi Mahkamah Konstitusi dalam struktur kelembagaan negara sebagai lembaga yang sejajar dengan Majelis Permusyawaratan Rakyat, Dewan Perwakilan Rakyat, Dewan Perwakilan Daerah, Presiden, Mahkamah Agung dan Komisi Yudisial telah mempertegas bahwa Mahkamah Konstitusi adalah lembaga yang memiliki otoritas tingi dalam koridor kewenangannya.

Pasal 24C Undang-Undang Dasar Republik Indonesia 1945 Juncto Pasal 10 UndangUndang Nomor 8 Tahun 2011 Tentang Mahkamah Konstitusi, dalam menjalankan fungsinya mengawal konstitusi, Mahkamah Konstitusi mempunyai 4 (empat) kewenangan dan 1 (satu) kewajiban dengan perincian sebagai berikut: menguji undang-undang terhadap UndangUndang Dasar (judicial review), memutus sengketa kewenangan lembaga negara yang kewenangannya diberikan oleh Undang-Undang dasar (disputes regarding state institution's authority), memutus pembubaran partai politik (political party's dissolution) dan memutus perselisihan tentang hasil pemilihan umum (disputes regarding General Election's result), dan wajib memberikan putusan atas pendapat Dewan Perwakilan Rakyat bahwa Presiden/Wakil Presiden telah melakukan pelanggaran hukum dan/atau pendapat bahwa Presiden dan/atau Wakil Presiden tidak lagi memenuhi syarat sebagai Presiden dan/atau Wakil Presiden.

Hingga saat ini, setidaknya sudah ada 80 negara di seluruh dunia yang telah mendirikan Mahkamah Konstitusi (Arief Ainul Yaqin, 2018, h. 1). Kewenangan yang dimiliki oleh Mahkamah Konstitusi di satu negara dengan negara lainnya memang bisa berbeda-beda. Akan tetapi, di antara beragam kewenangan berbeda-beda itu, ada satu kewenangan utama yang pasti dimiliki oleh semua Mahkamah Konstitusi di seluruh dunia, yakni kewenangan pengujian konstitusional atau yang disebut juga dengan judicial review.

Fungsi atau kewenangan judicial review itulah yang menjadi dasar pembentukan Mahkamah Konstitusi sejak pertama kali digagas oleh Hans Kelsen (Arief Ainul Yaqin, 2018, h. 2). Berdasarkan kewenangan Mahkamah Konstitusi tersebut, ketika terdapat pelanggaran terhadap hak konstitusional warga negara yang pelanggarannya terdapat dalam ketentuan aturan hukum atau regulasi dapat diluruskan melalui salah satu kewenangannya yaitu mekanisme judicial review.

Keberadaan mahkamah konstitusi sangat penting dalam mewujud nyatakan gagasan negara hukum dan demokrasi, sebagaimana dimaksud ketentuan Pasal 1 ayat 2 dan ayat 3 Undang-Undang Dasar Republik Indonesia 1945 yang salah satu ciri pentingnya adalah dijaminnya pemenuhan hak-hak konstitusional warga negara (I Dewa Gede Palguna, 2013, h. 13). Artinya, jika terdapat pelanggaran terhadap hak-hak konstitusional dimaksud maka harus 
Jurnal Ilmu Hukum FAKULTAS HUKUM UMSU
Kewenangan Mahkamah Konstitusi...(Benito Asdhie, Eza Ista)

Volume 4 Nomor 2, Juli-Desember 2019, 160-174

DOI: https://doi.org/10.30596/dll.v4i2.3174

disediakan mekanisme sebagai upaya hukum untuk mempertahankan hak-hak konstitusional tersebut melalui proses peradilan konstitusional (I Dewa Gede Palguna, 2013, h. 13).

Upaya hukum demikian tidak cukup hanya melalui mekanisme yang ada saat itu yaitu pengujian undang-undang terhadap Undang-Undang Dasar Republik Indonesia 1945 sebab pelanggaran terhadap hak-hak konstitusional warga negara bukan hanya dan tidak selalu terjadi karena adanya norma undang-undang yang bertentangan dengan Undang-Undang Dasar Republik Indonesia 1945, melainkan juga dapat terjadi karena adanya tindakan atau kelalaian lembaga negara atau pejabat public (state institutions, publics officials) (I Dewa Gede Palguna, 2013, h. 13).

Sebagai contoh, mengenai perkara penangkapan orang gara-gara mengambil kayu kebun miliknya oleh aparat, padahal kayu yang diambil hanya untuk keperluan rumah tangga dan tidak menimbulkan efek luas, namun akibat adanya salah tafsir oleh penegak hukum di lapangan, orang tersebut menjadi tersangka illegal loging (Heru Setiawan, 2017, h. 16). Tidak fair memang jika kesalahan tafsir dari lembaga publik mengenai pelaksanaan suatu aturan perundang-undangan dengan nyata merugikan hak konstitusional warga negara. Menghadapi permasalahan tersebut perlu rasanya Mahkamah Konstitusi mengadopsi kewenangan constitutional complaint atau Pengaduan Konstitusional yang merupakan salah satu bentuk upaya hukum perlindungan hak-hak konstitusional warga negara dalam sistem ketatanegaraan yang kewenangan untuk mengadilinya.

Pengaduan konstitusional merupakan pengaduan yang diajukan oleh perorangan ke Mahkamah Konstitusi terhadap perbuatan (atau kelalaian) suatu lembaga publik yang mengakibatkan terlanggarnya hak-hak dasar atau hak-hak konstitusional orang yang bersangkutan (I Dewa Gede Palguna, 2013, h. 2). Lazimnya hal itu baru dilakukan dan baru dapat diterima oleh Mahkamah Konstitusi, jika semua jalan penyelesaian melalui proses peradilan yang tersedia bagi persoalan tersebut telah tidak ada lagi (exhausted). Objek pengaduan konstitusional dapat ditujukan terhadap badan-badan pemerintahan, putusan pengadilan, atau undang-undang (I Dewa Gede Palguna, 2013, h. 2).

Padahal, alasan utama diadopsinya mekanisme peradilan konstitusional (constitutional adjudication) dalam sistem ketatanegaraan Indonesia, yang ditandai dengan dibentuknya Mahkamah Konstitusi, adalah agar konstitusi (in casu Undang-Undang Dasar Republik Indonesia 1945) sungguh-sungguh dijalankan atau ditegakkan dalam praktik sehingga konkordan dengan dianutnya paham negara hukum dalam Undang-Undang Dasar Republik Indonesia 1945 (I Dewa Gede Palguna, 2013, h. 3). Mengagungkan pengakuan hak asasi manusia tanpa perlindungan atau mendengung-dengungkan perlindungan tanpa tersedia upaya hukum yang cukup adalah sama-sama pengingkaran terhadap pengakuan dan perlindungan hak asasi setiap warga negara (Pan Mohamad Faiz, 2005, h. 4).

Ketiadaan pengaduan konstitusional sebagai kewenangan Mahkamah Konstitusi menimbulkan ketidakadilan dan ketidakpastian hukum di masyarakat karena jika keadaan demikian berlangsung terus menerus tanpa ada penyelesaian, hal itu jelas kontradiktif dengan gagasan negara hukum sebagai salah satu gagasan pokok yang mendasari dilakukannya 
Jurnal Ilmu Hukum FAKULTAS HUKUM UMSU
Kewenangan Mahkamah Konstitusi...(Benito Asdhie, Eza Ista)

Volume 4 Nomor 2, Juli-Desember 2019, 160-174 DOI: https://doi.org/10.30596/dll.v4i2.3174

perubahan terhadap Undang-Undang Dasar Republik Indonesia 1945 dan sekaligus merupakan jiwa dari keseluruhan ketentuan Undang-Undang Dasar Republik Indonesia 1945 sebagai sebuah sistem (I Dewa Gede Palguna, 2013, h. 5). Oleh karena itu, perlindungan terhadap hak asasi manusia hanya akan menikmati prioritas yang pantas jika badan peradilan khusus, in casu mahkamah konstitusi melaksanakan kewenangan pengaduan konstitusional terhadap kasuskasus nyata yang muncul dalam praktik (I Dewa Gede Palguna, 2013, h. 7). Berdasarkan pemaparan di atas, maka yang menjadi permasalahan dalam penelitian ini adalah bagaimana konsep pengaduan konstitusional sebagai bentuk perlindungan hak konstitusional warga negara, bagaimana alternatif penerapan kewenangan pengaduan konstitusional di Indonesia.

\section{METODE PENELITIAN}

Penulisan ini menggunakan metode penelitian hukum yuridis normatif (normatif research). Sesuai jenis dan sifat penelitiannya, maka sumber data yang digunakan dalam penulisan ini adalah data skunder yang terdiri dari bahan hukum primer berupa; peraturan perundang-undangan yang berkaitan dengan tema pembahasan. Bahan hukum sekunder dalam penelitian ini terdiri dari buku-buku, jurnal ilmiah, makalah dan artikel ilmiah yang dapat memberi penjelasan tentang bahan hukum primer. Sedangkan bahan hukum tersierberupa Kamus Besar Bahasa Indonesia (KBBI) dan lain sebagainya dalam menemukan defenisi dari istilah-istilah dalam membahas tentang Mahkamah Konstitusi.

Prosedur yang digunakan untuk mengumpulkan data dalam penilitian ini berupa dokumentasi berupa catatan atau kutipan, penelusuran literatur hukum, buku-buku dan lainnya yang bertalian dengan identifikasi masalah dalam penilitian dimaksud dengan cara offline maupun online. Pendekatan yang digunakan dalam penelitian ini adalah menggunakan pendekatan perundang-undangan. Maka analisa bahan hukum dilakukan adalah dengan menggunakan metode analisa konten (centent analysis method) yang dilakukan dengan menguraikan materi peristiwa hukum atau produk hukum secara rinci guna memudahkan interpretasi dalam pembahasan.

\section{PEMBAHASAN}

\section{Konsep Pengaduan Konstitusional Sebagai Bentuk Perlindungan Hak Konstitusional Warga Negara}

\section{Perlindungan Hak Konstitusional Warga Negara dalam Negara Hukum}

Konstruksi ketatanegaraan Indonesia pascaamandemen Undang-Undang Dasar Republik Indonesia 1945 secara normatif telah menegaskan paham konstitusional sebagai dasar penyelenggaraan negara (Ismail Hasani, 2013, h. 505). Pasal 1 ayat 2Undang-Undang Dasar Republik Indonesia 1945 menyebutkan bahwa Kedaulatan berada di tangan rakyat dan dilaksanakan menurut Undang-Undang Dasar Republik Indonesia 1945. Sedangkan pada Pasal 1 ayat 3 Undang-Undang Dasar Republik Indonesia 1945, Negara Indonesia adalah negara hukum. Rumusan dua ayat yang disepakati pada perubahan ketiga Undang-Undang Dasar Republik Indonesia 1945 merupakan tonggak penegasan demokrasi konstitusional Indonesia 
Jurnal Ilmu Hukum FAKULTAS HUKUM UMSU
Kewenangan Mahkamah Konstitusi...(Benito Asdhie, Eza Ista)

Volume 4 Nomor 2, Juli-Desember 2019, 160-174 DOI: https://doi.org/10.30596/dll.v4i2.3174

(Ismail Hasani, 2013, h. 505). Pada dasarnya kehidupan manusia tidak dapat dipisahkan dari hukum.Sepanjang sejarah peradaban manusia, peran sentral hukum dalam upaya menciptakan suasana yang memungkinkan manusia merasa terlindungi, hidup berdampingan secara damai dan menjaga eksistensinya di dunia telah diakui (Hamzah Baharuddin, 2010, h. 9).

Hak konstitusional yang dicantumkan dalam konstitusi akan menjadi bagian dari konstitusi sehingga seluruh cabang kekuasaan negara wajib menghormatinya. Oleh sebab itu, pengakuan dan penghormatan terhadap hak-hak konstitusional sebagai bagian dari konstitusi sekaligus juga berarti pembatasan terhadap kekuasaan negara (I Gede Dewa Palguna,2013: 111). Selanjutnya, sebagai bagian dari konstitusi maka hak-hak konstitusional itu harus dilindungi, sehingga diperlukan suatu mekanisme untuk mewujudkan perlindungan atas hak konstitusional tersebut. Mekanisme atau jalan hukum bagi perlindungan terhadap hak konstitusional tersebut dapat berupa mekanisme yudisial (melalui proses peradilan) maupun non yudisial (di luar proses peradilan) (Galuh Candra Purnamasari, 2017, h. 248).

Perlindungan terhadap hak konstitusional warga negara juga berkaitan dengan teori kedaulan rakyat. Teori Kedaulatan rakyat menjadi alternatif atas terjadinya sekularisasi (pemisahan dasar kekuasaan raja dari Tuhan). Di dalam teori ini, dikatakan bahwa raja atau pemerintah itu berkuasa bukan karena Tuhan melainkan karena social contract di mana rakyat meresidukan sebagian hak asasi manusianya untuk diurus oleh raja demi kepentingan bersama.Adagium yang dikembankan tidak lagi vox Dei sebagai dasar kekuasaan raja tetapi diganti dengan vox populi vox dei.Akhirnya, pemimpin hanya menerima residu berdasarkan konstitusi dan bukan sebaliknya (Majda El Muhtaj, 2005, h. 46).

Di dalam perkembangan kewenangan yang telah diberikan oleh Undang-Undang Dasar Republik Indonesia 1945 tersebut tidak serta merta dapat menjamin keadilan substantif yang terkandung dalam konstitusi. Terbukti dalam putusan-putusan Mahkamah Konstitusi, banyak perkara Mahkamah Konstitusi yang pada dasarnya merupakan bagian dari problematika praktek atau permasalahan aplikasi (application of norm) yang sejatinya bukan disebabkan berlakunya norma dalam undang-undang terhadap Undang-Undang Dasar Republik Indonesia 1945 (constitutional problem) nemun tetap mengusik rasa keadilan hak-hak konstitusional para warga yang notabene tidak diatur dalam Undang-Undang Dasar Republik Indonesia 1945 yaitu pengaduan konstitusional (constitutional complaint) (Majda El Muhtaj, 2005, h. 836).

Perlindungan hak-hak konstitusional akan menikmati pengutamaan yang memadai hanya jika Mahkamah Konstitusi diberi kewenangan melakukan pengujian konstitusional terhadap kasus-kasus nyata dalam praktik (I Dewa Gede Palguna, 2013: 176). Dengan kata lain, adanya kewenangan mahkamah konstitusi untuk mengadili perkara Pengaduan Konstitusional (constitutional complaint) adalah jaminan bahwa hak-hak konstitusional akan benar-benar ditaati dalam praktik (I Dewa Gede Palguna, 2013, h. 176).

\section{Urgensi Kewenangan Pengaduan Konstitusional}

Konstitusi Indonesia telah menegaskan bahwa negara Indonesia adalah negara hukum.Norma ini bermakna dalam Negara Republik Indonesia, hukum merupakan urat nadi 
Jurnal Ilmu Hukum FAKULTAS HUKUM UMSU
Kewenangan Mahkamah Konstitusi...(Benito Asdhie, Eza Ista)

Volume 4 Nomor 2, Juli-Desember 2019, 160-174

DOI: https://doi.org/10.30596/dll.v4i2.3174

seluruh aspek kehidupan. Salah satu unsur yang mutlak harus ada dalam negara hukum adalah pemenuhan akan hak-hak dasar manusia (basic rights) (Jimly Asshiddiqie, 2010, h. 343).

Suatu negara hukum mengharuskan adanya pengakuan normatif dan empiris terhadap prinsip supremasi hukum, yaitu bahwa semua masalah diselesaikan dengan hukum sebagai pedoman tertinggi. Pengakuan normatif mengenai supremasi hukum terwujud dalam pembentukan norma hukum secara hierarkis yang berpuncak pada supremasi konstitusi. Sedangkan secara empiris terwujud dalam perilaku pemerintahan dan masyarakat yang mendasarkan pada aturan hukum (Melalui, https:// jekisepriady .blogspot. com/ 2019 /02/efektivitas-lembaga-negara-dalam-sistem.html)

Konsekuensi logis dari kenyataan bahwa tanpa konstitusi negara tidak mungkin terbentuk, maka konstitusi menempati posisi yang sangat krusial dalam kehidupan ketatanegaraan suatu negara, ibarat "perjalanan cinta Romeo dan Juliet yang setia dan abadi" (Dahlan Thaib, dkk, 2015, h. 54).

Indonesia sebagai negara hukum yang menganut supremasi konstitusi yang tidak terlepas dari tiga hal, yaitu konstitusi, konstitusional dan konstitusionalisme.Konstitusi adalah segala ketentuan dan aturan mengenai ketatanegaraan atau Undang-Undang Dasar suatu negara.Konstitusional adalah segala tindakan atau perilaku yang didasarkan konstitusi dan konstitusionalisme adalah suatu paham mengenai pembatasan kekuasaan dan jaminan hak-hak rakyat melalui konstitusi. Salah satu unsur dari negara hukum adalah pemenuhan terhadap hakhak dasar warga negara dan paham konstitusi. (Achmad Edi Subiyanto, 2012, h. 3).

Ruang lingkup paham konstitusi (konstitusionalisme) terdiri dari: (Melalui, http://jeritansangpenyair.blogspot.com/2010/04/konstitusionalisasi-hukum-islam.html)

1) Anatomi kekuasaan (kekuasaan politik) tunduk pada hukum

2) Jaminan dan perlindungan hak-hak asasi manusia

3) Peradilan yang bebas dan mandiri

4) Pertanggung jawaban kepada rakyat (akuntabilitas publik) sebagai sendi utama dari asas kedaulatan rakyat.

Di Indonesia, diakuinya hak-hak asasi manusia sebagai hak konstitusi sebagaimana diatur dalam Pasal 28, Pasal 28A sampai dengan Pasal 28J, serta hak-hak warga negara Pasal 27, Pasal 30, dan Pasal 31 Undang-Undang Dasar Republik Indonesia 1945. Terhadap hak-hak tersebut, tentunya negara harus menghormati, melindungi atau memenuhi, di samping juga adanya hak warga negara yang timbul karena adanya kewajiban dari negara sebagaimana dinyatakan dalam Pasal 33 ayat 3 Undang-Undang Dasar Republik Indonesia 1945. Dengan demikian pemenuhan dan perlindungan hak asasi manusia di level negara harus mendapat jaminan dalam konstitusi negara dan peraturan perundang-undangan turunan dari konstitusi negara tersebut (Dahlan Thaib, dkk, 2015, h. 54).

Hak-hak tersebut jika dilanggar atau bahkan diabaikan oleh produk hukum yang dikeluarkan oleh aparatur negara, adakah mekanisme hukum yang tersedia untuk menjamin hak-hak konstitusional, karena hak-hak tersebut tidak cukup hanya sebatas pengakuan tertulis dalam dokumen, tetapi harus ada perlindungan yang nyata yang benar-benar mampu menjamin 
DEIEGA LATA

Jurnal Ilmu Hukum

FAKULTAS HUKUM UMSU
Kewenangan Mahkamah Konstitusi...(Benito Asdhie, Eza Ista)

Volume 4 Nomor 2, Juli-Desember 2019, 160-174

DOI: https://doi.org/10.30596/dll.v4i2.3174

dan melindungi hak-hak dasar warga negara (Melalui, $\underline{\text { https://text- }}$ id.123dok.com/document/oz1dgvz9-penegakan-hak-konstitusional-melalui-constitutionalcomplaint-sebagai-perwujudan-negara-hukum.html)

Indonesia telah menjadikan constitutional review sebagai mekanisme perlindungan hak konstitusional tersebut. Haruslah diakui bahwa kehadiran mekanisme constitutional review di Indonesia melalui Mahkamah Konstitusi telah banyak member sumbangan bagi penyehatan sitem ketatanegaraan dan hukum nasional. Pada masa lalu banyak sekali undang-undang yang dibuat secara sepihak oleh pemerintah (dan DPR hanya dijadikan semacam rubber stamp) tanpa bisa dibatalkan meski isinya diindikasikan kuat melanggar Undang-Undang Dasar (Dahlan Thaib, dkk, 2015, h. 54).

Perubahan atas undang-undang yang bermasalah pada masa lalu hanyalah dapat dilakukan melalui legislative review yang dalam praktiknya sangat ditentukan oleh pemerintah.Bahkan kasus perubahan RUU Penyiaran tahun 1997 menjadi noda hitam yang sulit dihapus dari sejarah perjalanan legislasi Indonesia. Saat itu RUU Penyiaran tersebut sudah dibahas dan diperdebatkan dalam waktu yang lama di DPR sampai akhirnya pemerintah dan DPR menyetujui untuk diundangkan.Akan tetapi, begitu disampaikan kepada presiden untuk ditandatangani dan diundangkan ternyata presiden menolak dan meminta RUU itu dibahas kembali untuk diubah isinya sesuai dengan kehendak presiden (Dahlan Thaib, dkk, 2015, h. 54).

Bahwa dengan lahirnya Mahkamah Konstitusi, semua undang-undang yang dinilai bertentangan dengan Undang-Undang Dasar Republik Indonesia 1945 dapat dimintakan constitutional review untuk dinyatakan bertentangan dengan Undang-Undang Dasar Republik Indonesia 1945 atau inkonstitusional sehingga tak mempunyai kekuatan hukum mengikat. Apabila dilihat dari segi batu ujinya, constitutional review terbatas hanya pada pengujianpengujian yang dilakukan untuk menilai dan menguji konstitusionalitas suatu norma hukum dengan menggunakan konstitusi sebagai batu ujinya (Arief Ainul Yaqin, 2018, h. 25).

Konsep constitutional review berkembang dari gagasan modern tentang sistem pemerintahan demokratis yang didasarkan atas ide-ide negara hukum (rule of law), prinsip pemisahan kekuasaan (separation of power), serta perlindungan dan pemajuan hak asasi manusia (the protection of fundamental rights). Dalam constitutional review terdapat 2 (dua) tugas pokok yakni: (Melalui, https://puspanlakuu.dpr.go.id/produk/index-evaluasi/page/3)

1) Untuk menjamin berfungsinya sistem demokrasi dalam hubungan perimbangan peran atau interplay antar cabang kekuasaan legislatif, eksekutif dan yudikatif. Dengan kata lain, constitutional review dimaksudkan untuk mencegah terjadinya pendayagunaan kekuasaan oleh satu cabang kekuasaan lainnya;

2) Untuk melindungi setiap individu warga negara dari penyalahgunaan kekuasaan oleh lembaga negara yang merugikan hak fundamental warga negara yang dijamin dalam konstitusi.

Permasalahan mekanisme constitutional review di Indonesia adalah pembatasan bahwa yang dapat dilakukan pengujian konstitusionalitas hanyalah norma yang ada dalam suatu 
Jurnal Ilmu Hukum FAKULTAS HUKUM UMSU
Kewenangan Mahkamah Konstitusi...(Benito Asdhie, Eza Ista)

Volume 4 Nomor 2, Juli-Desember 2019, 160-174

DOI: https://doi.org/10.30596/dll.v4i2.3174

undang-undang. Dapat disimpulkan dari hal tersebut bahwa pembentuk undang-undang seakanakan berasumsi bahwa pelanggaran terhadap hak konstitusional warga negara hanya terjadi karena norma undang-undang.

Terhadap hal tersebut, pelanggaran hak konstitusional tentunya juga dapat terjadi akibat dari penerapan suatu norma undang-undang, interpretasi para penegak hukum terhadap undangundang tersebut, atau kebijakan yang dibuat oleh lembaga negara maupun pejabat publik juga dapat menyebabkan kerugian terhadap hak konstitusional warga negara. Sehingga, bukan semata-mata hanya undang-undang yang melanggar hak konstitusional warga negara. Namun untuk masalah pelanggarn hak konstitusional warga negara yang diakibatkan oleh kebijakan atau kelalaian pemerintah atau pejabat publik tidak dapat diselesaikan dengan mekanisme constitutional review yang hanya menguji sebatas norma dalam suatu undang-undang.

Saat ini terdapat beberapa peraturan yang dibuat oleh pemerintah yang dianggap bertentangan dengan Undang-Undang Dasar Republik Indonesia 1945 yang mengakibatkan timbulnya kerugian konstitusional bagi sebagian orang.Namun sampai saat ini belum adanya upaya hukum yang dapat dilakukan oleh pihak yang hak konstitusionalnya terlanggar akibat dari dikeluarkannya suatu kebijakan dan implementasi peraturan perundang-undangan. Hal ini menimbulkan problematika dilapangan karena pada dasarnya negara memberikan jaminan perlindungan hak konstitusional yang tercermin dalam setiap pasal di Undang-Undang Dasar Republik Indonesia 1945 namun sampai saat ini belum ada saluran hukum yang dapat dilakukan.

Fakta-fakta diatas menunjukkan bahwa constitutional review di Indonesia masih memiliki dua kelemahan yaitu:

1) Sempit dan terbatasnya ruang constitutional review di Indonesia karena hanya mencakup norma dalam suatu undang-undang saja;

2) Tidak adanya perlindungan bagi warga negara yang hak konstitusionalnya dilanggar akibat dari kelalaian atau perbuatan yang dibuat oleh lembaga negara ataupun pejabat publik.

Fakta empiris yang terjadi di lapangan menunjukkan banyak perkara yang diajukan ke Mahkamah Konstitusi yang terindikasi melanggar hak konstitusi, sementara semua upaya hukum yang telah ada ditempuh oleh pihak pengadu tidak dapat diterima atau ditarik kembali oleh pengadu sebelum proses peradilan dilakukan, oleh karena itu tidak tersedianya kewenangan mengadili perkara tersebut di Mahkamah Konstitusi, bahkan di semua lembaga peradilan di Indonesia.

Menanggapi permasalahan-permasalahan tersebut, perlu kiranya Mahkamah Konstitusi menambahkan pengaduan konstitusionalke dalam kewenangannya. Tidak adanya kewenangan Mahkamah Konstitusi RI untuk mengadili perkara pengaduan konstitusional menyebabkan tidak tersedianya upaya hukum (judicial remedy) melalui mekanisme peradilan konstitusional (constitutional adjudication) untuk pelanggaran terhadap hak-hak konstitusional warga negara yang terjadi bukan karena inkonstitusionalitas norma undang-undang melainkan karena adanya perbuatan maupun kelalaian lembaga negara atau pejabat publik (state institutions, public officials) (I Dewa Gede Palguna, 2013, h. 4). 
Kewenangan Mahkamah Konstitusi...(Benito Asdhie, Eza Ista)

Sementara semua upaya hukum yang tersedia berdasarkan sistem yang berlaku saat ini telah ditempuh oleh pihak pengadu atau pelapor (complainant) (I Dewa Gede Palguna, 2013, h. 5). Salah satu akibatnya, banyak permohonan yang diajukan ke Mahkamah Konstitusi RI yang secara substansial merupakan pengaduan konstitusional, dinyatakan "tidak dapat diterima" (niet ontvankelijk verklaard) dengan alasan Mahkamah Konstitusi tidak berwenang untuk mengadilinya (I Dewa Gede Palguna, 2013, h. 5). Jika keadaan demikian berlangsung terus tanpa ada penyelesaian, hal itu jelas kontradiktif dengan gagasan negara hukum sebagai salah satu gagasan pokok yang mendasari dilakukannya perubahan terhadap Undang-Undang Dasar Republik Indonesia 1945 dan sekaligus merupakan jiwa dari keseluruhan ketentuan Undang-Undang Dasar Republik Indonesia 1945 sebagai sebuah sistem (I Dewa Gede Palguna, 2013, h. 5).

Tiga objek pengaduan konstitusionalini masih berkembang karena bukan tidak mungkin pejabat negara atau lembaga negara melakukan penzaliman yang melanggar hak-hak konstitusional (I Dewa Gede Palguna, 2013, h. 5). Melalui pengaduan konstitusional, setiap warga negara yang hak konstitusionalnya dilanggar, tetapi tidak ada lagi jalur pengadilan yang dapat menyelesaikannya karena semua upaya hukum sudah ditempuh dan sudah final, yang bersangkutan dapat mengajukan perkara ke Mahkamah Konstitusi melalui pengaduan konstitusional (Melalui, http://ahmadfurkoninglar.blogspot.com/2012_11_26_archive.html)

Sebagai salah satu mekanisme perlindungan hak-hak konstitusional warga negara, pengaduan konstitusional lebih kuat jika dibandingkan dengan constitutional review, baik dalam bentuk abstrak maupun konkret.Hal itu dikarenakan dalam pengaduan konstitusional individu warga negara secara langsung dapat membawa masalah pelanggaran terhadap hak konstitusionalnya ke Mahkamah Konstitusi, sedangkan dalam mekanisme constitutional review akses ke Mahkamah Konstitusi itu hanya dapat dilakukan secara tidak langsung (I Dewa Gede Palguna, 2013, h. 310).

Berdasarkan uraian diatas jelas bahwa kewenangan Mahkamah Konstitusi untuk mengadili perkara pengaduan konstitusional merupakan sesuatu yang melekat dalam fungsi Mahkamah Konstitusi untuk melaksanakan constitutional review (I Dewa Gede Palguna, 2013, h. 310). Pemberian kewenangan mengadili perkarapengaduan konstitusional kepada Mahkamah Konstitusi dinilai akan memberi kontribusi pada upaya untuk memperkuat penghormatan terhadap hak-hak dan kebebasan-kebebasan mendasar manusia pada umumnya dan warga negara pada khususnya, mengintensifkan perlindungan terhadap hak-hak tersebut dan sekaligus mempertegas derajat konstitusional hak-hak dan kebebasan-kebebasan itu (I Dewa Gede Palguna, 2013, h. 311).

Tujuan pembentukan Mahkamah Konstitusi menurut latar belakang historisnya memang tidak bisa dipisahkan dari tujuan untuk meningkatkan perlindungan terhadap hak konstitusional warga negara. Sebagaimana dikatakan oleh Donald L. Horowitz "Constitutional courts can contribute to making a new regime not merely a democracy but a state governed by law and respectful of its citizens" (Mahkamah Konstitusi dapat berkontribusi untuk menciptakan sebuah rezim baru, tidak hanya demokrasi tetapi juga pemerintahan yang berdasarkan atas hukum yang 
Jurnal Ilmu Hukum FAKULTAS HUKUM UMSU
Kewenangan Mahkamah Konstitusi...(Benito Asdhie, Eza Ista)

Volume 4 Nomor 2, Juli-Desember 2019, 160-174

DOI: https://doi.org/10.30596/dll.v4i2.3174

menghormati hak-hak konstitusional warganya) (Arief Ainul Yaqin, 2018, h. 15).

Hanya jika Mahkamah Konstitusi diberi kewenangan untuk mengadili kasus-kasus nyata yang lahir dalam praktik seperti itulah baru dapat dikatakan bahwa hak-hak dan kebebasankebebasan yang dijamin oleh konstitusi itu telah menikmati atau menempati prioritas yang pantas (Arief Ainul Yaqin, 2018, h. 15).

Bagi negara-negara yang sedang mengalami proses transisi menuju demokrasi, pengaduan konstitusional dipandang bukan sekedar jaminan perlindungan hak-hak konstitusional warga negara terhadap perbuatan sewenang-wenang penguasa melainkan juga sebagai sarana penting untuk membangun demokrasi konstitusional yang berlandaskan pada penghormatan terhadap hak-hak asasi manusia (Arief Ainul Yaqin, 2018, h. 15).

Selain itu, sebagai instrument khusus perlindungan hak-hak konstitusional seseorang, pengaduan konstitusional memberi warga negara suatu hak untuk memasuki sengketa hukum melawan negara, beserta aparatnya. Dengan demikian, berarti pengaduan konstitusional memfasilitasi integrasi warga negara dalam proses pengelolaan negara dan masyarakat (Arief Ainul Yaqin, 2018, h. 15).

\section{Alternatif Penerapan Pengaduan Konstitusional di Indonesia}

\section{Mahkamah Konstitusi sebagai Lembaga yang Berwenang Mengadili Pengaduan Konstitusional}

Terjadinya perubahan fundamental dalam sistem ketatanegaraan Indonesia, yaitu dari sistem supremasi Majelis Permusyawaratan Rakyat (MPR) menjadi sistem supremasi konstitusi, membawa satu pertanyaan mendasar sebagai konsekuensi logisnya: siapa yang menjamin bahwa seluruh praktik ketatanegaraan Indonesia benar-benar tidak bertentangan dengan Undang-Undang Dasar Republik Indonesia 1945 atau bagaimana caranya agar UndangUndang Dasar Republik Indonesia 1945 itu benar-benar ditaati dalam praktik penyelenggaraan kehidupan bernegara sehari-hari. Dari pertanyaan inilah kemudian lahir kebutuhan akan adanya suatu lembaga yang bertugas untuk menjamin bahwa UUD NRI 1945 benar-benar ditaati dalam kehidupan sehari-hari, yaitu Mahkamah Konstitusi RI (I Dewa Gede Palguna, 2013, h. 544).

Secara sederhana, konstitusi merupakan hukum dasar yang disusun secara sistematis guna menata dan mengatur pokok-pokok struktur dan fungsi lembaga-lembaga negara, termasuk dalam hal ihwal kewenangan dan batas kewenangan lembaga-lembaga itu (Saldi Isra, 2019, h. 1). Wacana tentang kemungkinan penerapan Pengaduan Konstitusional di Indonesia tentunya tidak terlepas dari kewenangan Mahkamah Konstitusi sebagai salah satu pelaksana kekuasaan kehakiman. Pengaduan Konstitusional yang notabene berada dalam ranah pengujian konstitusional (constitutional review) jelas berada dalam area kewenangan Mahkamah Konstitusi.

Melekatnya secara teoritis kewenangan mengadili perkara Pengaduan Konstitusional pada Mahkamah Konstitusi juga dapat dijelaskan berdasarkan ciri khas atau karakteristik mahkamah konstitusi sebagai organ atau lembaga yang diberi fungsi untuk melaksanakan constitutional review (I Dewa Gede Palguna, 2013, h. 312). 
Jurnal Ilmu Hukum FAKULTAS HUKUM UMSU
Kewenangan Mahkamah Konstitusi...(Benito Asdhie, Eza Ista)

Volume 4 Nomor 2, Juli-Desember 2019, 160-174

DOI: https://doi.org/10.30596/dll.v4i2.3174

Pentingnya kewenangan untuk mengadili perkara Pengaduan Konstitusional itu diberikan kepada mahkamah konstitusi bukan semata-mata dikarenakan bahwa warga negara akan bersengketa secara hukum dengan negara, melainkan juga karena adanya karakter yang spesifik dari Pengaduan Konstitusional sebagai bentuk pengawasan terhadap negara dalam hubungannya dengan subjek yang berhak untuk mengajukan pengaduan, objek pengaduan, aturan-aturan khas yang berkait dengan prosedur pengaduan dan penerimaan pengaduan itu, serta konsekuensi-konsekuensi yuridis penerimaan pengaduan tersebut (I Dewa Gede Palguna, 2013, h. 312). Namun kedudukan Mahkamah Konstitusi dalam struktur ketatanegaraan Indonesia nyatanya telah mendukung untuk mewadahi Pengaduan Konstitusional.

Sebagaimana telah dijelaskan, Mahkamah Konstitusi dibentuk adalah untuk melaksanakan melaksanakan fungsi constitutional review. Salah satu dari tugas constitutional review adalah melindungi hak-hak konstitusional warga negara dari pelanggaran yang dilakukan oleh cabang-cabang kekuasaan negara. Pengaduan Konstitusional adalah salah satu perwujudan atau bentuk dari constitutional review tersebut (I Dewa Gede Palguna, 2013, h. 312).

Terjelmanya atau ditaatinya konstitusi dalam praktik merupakan syarat untuk mewujudkan konstitusi (Undang-Undang Dasar Republik Indonesia 1945) sebagai undangundang dasar yang mencerminkan gagasan kedaulatan rakyat dan gagasan negara hukum yang dijadikan acuan dalam melakukan perubahan UUD NRI 1945. Menerima kehadiran Mahkamah Konstitusi RI sebagai bagian tak terpisahkan dari cita cita mewujudkan negara hukum dengan menerapkan prinsip supremasi konstitusi berarti secara teoritik juga menerima kewenangan Mahkamah Konstitusi RI untuk mengadili perkara Pengaduan Konstitusional yang merupakan bagian dari fungsi constitutional review Mahkamah Konstitusi RI guna memberi perlindungan yang maksimum terhadap hak-hak konstitusional warga negara (I Dewa Gede Palguna, 2013, h. 312).

\section{Alternatif Dasar Kewenangan Pengaduan Konstitusional dalam Sistem Hukum di Indonesia Melalui Perubahan Undang-Undang Dasar Negara Republik Indonesia Tahun 1945}

Sebagai hasil olah pikir manusia pada zamannya, hukum dalam bentuk apapun termasuk konstitusi atau undang-undang dasar mungkin terasa sulit mengikuti perkembangan zaman. Apalagi konstitusi merupakan resultante atau kesepakatan lembaga yang membuatnya sesuai dengan keadaan sosial, politik, ekonomi pada saat dibuat (Saldi Isra, 2010, h. 221). Agar menjadi tidak tertinggal dengan kebutuhan hukum masyarakatnya, perubahan menjadi sesuatu yang niscaya. Secara hukum, keniscayaan tersebut pulalah yang menjadikan sebuah konstitusi harus merumuskan pengaturan bagaimana mengubah konstitusi itu sendiri (Saldi Isra, 2010: 221).

Dimilikinya kewenangan mengadili Pengaduan Konstitusional merupakan tuntutan kebutuhan hanya saja untuk mewujudkannya tidaklah mudah sebab kewenangan Mahkamah Konstitusi RI diatur dan ditentukan secara limitatif dalam Pasal 24C ayat (1) Undang-Undang Dasar Republik Indonesia 1945. Artinya, secara legal formal, jika hendak menambahkan 
Jurnal Ilmu Hukum FAKULTAS HUKUM UMSU
Kewenangan Mahkamah Konstitusi...(Benito Asdhie, Eza Ista)

Volume 4 Nomor 2, Juli-Desember 2019, 160-174 DOI: https://doi.org/10.30596/dll.v4i2.3174

kewenangan mengadili perkara Pengaduan Konstitusional kepada Mahkamah Konstitusi RI maka hal itu harus dilakukan dengan melakukan perubahan terhadap rumusan limitatif dalam Undang-Undang Dasar Republik Indonesia 1945 (I Dewa Gede Palguna, 2013: 583). Sementara pada saat ini melakukan perubahan terhadap Undang-Undang Dasar Republik Indonesia 1945 bukanlah hal yang mudah, baik secara politik maupun prosedural (I Dewa Gede Palguna, 2013, h. 583).

Tatkala rencana perubahan terhadap Undang-Undang Dasar Republik Indonesia 1945 mulai dibicarakan pada Sidang Umum MPR 1999, seluruh fraksi yang ada di MPR (11 fraksi) hasil Pemilihan Umum 1999 menyepakati 5 hal dalam melakukan perubahan terhadap UndangUndang Dasar Republik Indonesia 1945, yaitu: (I Dewa Gede Palguna, 2013, h. 494).

a) Tidak mengubah Pembukaan Undang-Undang Dasar Republik Indonesia 1945

b) Tetap mempertahankan Negara Kesatuan Republik Indonesia

c) Mempertegas sistem pemerintahan presidensial

d) Penjelasan Undang-Undang Dasar Republik Indonesia 1945 ditiadakan serta hal-hal normative dalam penjelasan dimaksukkan ke dalam pasal-pasal.

e) Perubahan dilakukan dengan cara addendum.

Berdasarkan uraian diatas, untuk menambahkan kewenangan Pengaduan Konstitusional kepada Mahkamah Konstitusi haruslah berdasarkan ketentuan Pasal 37 Undang-Undang Dasar Republik Indonesia 1945.

\section{Tanpa Melalui Perubahan Undang-Undang Dasar Negara Republik Indonesia Tahun 1945}

Argumentasi perlindungan hak konstitusional baru muncul setelah lahirnya UndangUndang Nomor 24 Tahun 2003 Tentang Mahkamah Konstitusi (UU MK), khususnya dalam ketentuan tentang siapa pihak yang dapat mengajukan permohonan pengujian undang-undang, yaitu Pasal 51 ayat 1 UU MK yang pada intinya menyatrakan bahwa pihak yang dapat menjadi pemohon dalam permohonan pengujian undang-undang terhadap Undang-Undang Dasar Republik Indonesia 1945 adalah pihak yang menganggap hak dan/atau kewenangan konstitusionalnya dirugikan oleh berlakunya suatu undang-undang (I Dewa Gede Palguna, 2013, h. 564).

Pengaduan Konstitusional telah yang menjadi kebutuhan untuk pengoptimalan terhadap perlindungan hak konstitusional warga negara. Namun kewenangan Mahkamah Konstitusi dilimitasi di pasal 24C ayat 1 dan sulitnya dilakukan perubahan Undang-Undang Dasar Republik Indonesia 1945. Adapun realitas fakta empirik terhadap tuntutan perlunya diperluas kewenangan Mahkamah Konstitusi tidak mungkin dibiarkan begitu saja, konsekuensi sebagai negara hukum yang melindungi hak konstitusional warga negara haruslah berbanding lurus dengan implementasinya, oleh karena itu diperlukan alternatif lain untuk memperluas kewenangan Mahkamah Konstitusi.

\section{Alternatif Mekanisme Pelaksanaan Pengaduan Konstitusional}


Jurnal Ilmu Hukum

FAKULTAS HUKUM UMSU
Kewenangan Mahkamah Konstitusi...(Benito Asdhie, Eza Ista)

Volume 4 Nomor 2, Juli-Desember 2019, 160-174

DOI: https://doi.org/10.30596/dll.v4i2.3174

Ada beberapa persyaratan yang harus dipertimbangkan jika Mahkamah Konstitusi Republik Indonesia hendak mengadopsi mekanisme pengaduan konstitusional, yaitu: (Pan Mohamad Faiz. 2016, h. 114-115)

1) Struktur organisasi di Mahkamah Konstitusi RI harus diperkuat terutama penambahan jumlah peneliti konstitusi yang terlatih dan berpengalaman dan panitera untuk medukung peradilan konstitusi dalam memeriksa kasus dan membuat keputusan.

2) Mahkamah Konstitusi seharusnya diberikan kewenangan melakukan pemeriksaan pendahuluan oleh hakim panel, bukan oleh pendaftar atau pegawai administrasi, untuk memilah apakah sebuah kasus dapat diuji lebih lanjut di pengadilan untuk diperiksa atau seharusnya langsung dihentikan. Mekanisme penyaringan ini dibutuhkan untuk memastikan Mahkamah Konstitusi menangani kasus yang tepat.

3) Mahkamah Konstitusi harus membuat batasan yang jelas mengenai kasus Pengaduan Konstitusional yang dapat diuji. Batasan tersebut diantaranya:

a) Pihak yang mengajukan haruslah orang yang secara langsung mengalami kerugian hak konstitusional;

b) Permohonan hanya dapat dilakukan setelah pemohon melakukan semua upaya hukum.

c) Harus ada pembatasan waktu untuk penerimaan kasus Pengaduan Konstitusional setelah putusan pengadilan, tindakan atau perbuatan pejabat publik atau lembaga negara yang melanggar hak konstitusional pemohon.

Salah satu fungsi dari Mahkamah Konstitusi adalah sebagai pelindung hak konstitusional warga negara (the protector of citizen's constitutional rights). Fungsi ini berkaitan dengan materi muatan konstitusi yaitu memberikan jaminan terhadap hak konstitusional warga negara (Eka Nam Sihombing, 2018, h. 80). Maka dengan diberikannya kewenangan Pengaduan Konstitusional kepada Mahkamah Konstitusi Republik Indonesia beserta alternatif penambahan dan penerapannya jika kelak diberikan, diharapkan dapat mewujudkan cita negara hukum dan perlindungan maksimal terhadap perlindungan hak konstitusional warga negara.

\section{KESIMPULAN DAN SARAN Kesimpulan}

Pengaduan konstitusional adalah salah satu mekanisme pertahanan diri bagi warga negara untuk mempertahankan hak-hak konstitusionalnya melalui pengadilan terhadap pelaksanaan kekuasaan negara. Mahkamah konstitusi atau pengadilan dengan nama lain yang diberi fungsi sebagai mahkamah konstitusi memegang peran kunci dalam hal ini sebab melalui kewenangan yang ada padanya untuk memutus perkara Pengaduan konstitusional, mahkamah konstitusi bukan sekedar mengawal konstitusi tetapi sekaligus berarti menjadi pelindung hak-hak konstitusional.

Tidak adanya kewenangan Mahkamah Konstitusi RI untuk mengadili perkara Pengaduan konstitusional menyebabkan tidak tersedianya upaya hukum (judicial remedy) melalui mekanisme peradilan konstitusional (constitutional adjudication) untuk pelanggaran terhadap hak-hak konstitusional warga negara yang terjadi bukan karena inkonstitusionalitas norma undang-undang melainkan karena adanya perbuatan maupun kelalaian lembaga negara atau pejabat publik (state institutions, public officials). Salah satu akibatnya, banyak 
permohonan yang diajukan ke Mahkamah Konstitusi RI yang secara substansial merupakan Pengaduan konstitusional, dinyatakan "tidak dapat diterima"(niet ontvankelijk verklaard) dengan alasan Mahkamah Konstitusi tidak berwenang untuk mengadilinya.

\section{Saran}

Sebaiknya pembuat peraturan perundang-undangan merumuskan kembali Pengaduan konstitusional menjadi bagian dari kewenangan Mahkamah Konstitusi karena urgensi dari penerapan kewenangan ini sebagai salah satu upaya untuk memberikan perlindungan maksimal terhadap hak konstitusional warga negara. Melihat beberapa kasus yang dinyatakan "tidak dapat diterima" karena merupakan Pengaduan konstitusional dan bukan termasuk ranah kewenanganMahkamah Konstitusi kiranya perlu Mahkamah Konstitusi menambahkan mekanisme ini dalam kewenangannya dan mengatur mengenai hukum acara apabila kelak kewenangan ini diberikan kepada Mahkamah Konstitusi. 
Kewenangan Mahkamah Konstitusi...(Benito Asdhie, Eza Ista) Volume 4 Nomor 2, Juli-Desember 2019, 160-174 DOI: https://doi.org/10.30596/dll.v4i2.3174

\section{DAFTAR PUSTAKA}

Asshiddiqie, Jimly. (2010). Pengantar Ilmu Hukum Tata Negara. Jakarta: Rajawali Press.

Baharuddin, Hamzah. 2010. Bunga Rampai dalam Kontroversi Isu. Makassar: Pustaka Refleksi.

Faiz, Mohamad. Pan. A Prospect and Challenges For Adopting Constitutional Complaint and Constitutional Question In The Indonesian Constitutional Court. Constitutional Review Vol.2 No.1 Mei 2016.

Hasani, Ismail. (2013). Masa Depan Mahkamah Konstitusi RI Naskah Konferensi Mahkamah Konstitusi dan Pemajuan Hak Konstitusional Warga. Jakarta: Pustaka Masyarakat Setara.

Isra, Saldi. (2010). Pergeseran Fungsi Legislasi. Jakarta: PT Raja Grafindo Persada.

Isra, Saldi. (2019). Sistem Pemerintahan Indonesia Pergulatan Ketatanegaraan Menuju Sistem Pemerintahan Presidensial. Jakarta: PT Raja Grafindo Persada.

Muhtaj, El. Majda. (2005). Hak Asasi Manusia dalam Konstitusi Indonesia dari UUD 1945 Sampai Dengan Perubahan UUD 1945 Tahun 2002. Jakarta: Kencana Prenada Meida Group.

Palguna, I Gede Dewa. (2013). Pengaduan Konstitusional (Constitutional Complaint) Upaya Hukum terhadap pelanggaran hak-hak konstitusional warga negara. Jakarta: Sinar Grafika.

Purnamasari, Candra. Galuh. (2017). Upaya Hukum Terhadap Pelanggaran Hak-Hak Konstitusional Warga Negara Melalui Pengaduan Konstitusional (Constitutional Complaint). Jurnal Vej Vol. 3 No. 2. Desember 2017.

Setiawan, Heru. (2017). Mempertimbangkan Constitutional Complaint Sebagai Kewenangan Mahkamah Konstitusi. Lex Jurnalica Vol. 14 No. 1 April 2017.

Sihombing, Nam Eka. Hukum Kelembagaan Negara. Yogyakarta: Ruas Media. 2018.

Soekanto, Soerjono., \& Sri, Mamudji. Penelitian Hukum Normatif (Suatu Tinjauan Singkat). Jakarta: Raja Grafindo. 2014.

Thaib, Dahlan. dkk. (2015). Teori dan Hukum Konstitusi. Jakarta: PT. Raja Grafindo Persada.

Yaqin, Ainul., \& Arief. (2018). Constitutional question Kewenangan yang terlupakan dan gagasan untuk melembagakannya di Mahkamah Konstitusi. Jakarta: Sinar Grafika. 